Aneta Wysocka (1)

Uniwersytet Marii Curie-Skłodowskiej, Lublin

aneta.wysocka@poczta.umcs.lublin.pl

\title{
PROZODIA, SEMANTYKA, STYL - O HIERARCHII POZIOMÓW EKWIWALENCJI W TŁUMACZENIU PIOSENKI KABARETOWEJ (STUDIUM PRZYPADKU: POLSKOJĘZYCZNE WARIANTY MONEY... FREDA EBBA)
}

Słowa klucze: przekład piosenki, poziomy ekwiwalencji przekładu, warianty przekładu, przekład komunikatu multimodalnego, Wojciech Młynarski jako tłumacz

Keywords: song translation, levels of equivalence in translation, translation variants, multi-modal translation, Wojciech Młynarski as a translator

\section{Wprowadzenie: warianty przekładu jako zapis zmagań tłumacza}

Tłumaczenie piosenki kabaretowej, czyli komunikatu multimodalnego, którego semantykę współtworzą komponenty werbalne i muzyczne, a także ruch, kostium, rekwizyt i scenografia, można uznać za zadanie trudniejsze nawet od przekładu tekstu poetyckiego. Uzyskanie pełnej ekwiwalencji wobec oryginału na wszystkich poziomach organizacji takiego komunikatu nie jest możliwe, toteż kluczową sprawą staje się - zgodnie z klasycznym ujęciem Wernera Kollera (Lewicki 2017: 148-149) - hierarchizacja owych poziomów. Decyduje o niej sam tłumacz wybierający takie rozwiązania, które jego zdaniem dadzą efekt „adekwatności funkcjonalnej (functional adequacy)” czy też „podobieństwa odbioru (similar response)” (Tabakowska 2001: 9). Cel niniejszej pracy będzie stanowiła obserwacja tego, w jaki sposób owa hierarchia funkcjonuje i jak może się zmieniać w poszczególnych wariantach translacji, czyli „różnych przekładach tego samego oryginału” na jeden kod (Lewicki 2017: 174). 
Za materiał badawczy posłuży znany utwór Money... Freda Ebba (słowa) i Johna Kandera (muzyka) z musicalu Cabaret, który na grunt polskiej kultury i polskiego języka przeniósł Wojciech Młynarski. Maszynopis (z odręcznymi poprawkami) znajdujący się w archiwum Muzeum Literatury w Warszawie i libretto sygnowane nazwiskiem Młynarskiego świadczą o tym, że podchodził on do tej piosenki parokrotnie, $\mathrm{z}$ różnymi pomysłami na oddanie w polszczyźnie poszczególnych fragmentów angielskiego tekstu. Przypuszczał zapewne, że przekład popularnego dzieła - z pozoru komedii, będącej w istocie gorzką metaforą dziejów XX-wiecznej Europy - przez lata posłuży artystom rodzimej sceny. $Z$ właściwym sobie perfekcjonizmem dążył zatem do tego, by stworzyć jak najlepszą „reprezentację” (ibid. 2017) śpiewanych partii Kabaretu w polskiej kulturze i polskim języku.

\section{Translatorskie sposoby na ekwiwalencję brzmieniową}

O kryteriach, według których Młynarski oceniał jakość przekładu, można się dowiedzieć z wywiadów i listów. Rozproszone są w nich jego uwagi autotematyczne. Czytamy na przykład: „tłumaczenia naciągające, czy zmieniające dla wygody rytm oryginału, czy dające np. rym żeński w miejsce oryginalnego męskiego nie interesują mnie" (Młynarski 1983: 40). Zgodnie $\mathrm{z}$ tą deklaracją autor zwracał baczną uwagę na prozodyczną, czyli „muzyczną” (Pisarkowa 1998: 16) płaszczyznę tekstu. Aby odtworzyć efekt korelacji melodii i mowy, musiał przede wszystkim zadbać o wzajemną zgodność fraz muzycznych i tekstowych pod względem czasu trwania oraz akcentu wyrazowego nadającego wypowiedzi określony rytm ${ }^{1}$. W przypadku Money... jest to szczególnie istotne, ponieważ w tym właśnie utworze struktura rytmiczna współtworzy świat przedstawiony ${ }^{2}$ - atmosferę Berlina lat 30. XX w., czyli miasta i ludzi u progu katastrofy - co uwidacznia się w wykonaniu oryginalnej piosenki przez duet Lizy Minnelli z Joelem Greyem (1972)3. Postaci wykreowane przez dwoje artystów są karykaturalnie sztuczne między innymi za sprawą śpiewu charakteryzującego się silnym uwydatnianiem akcentów wyrazowych, występujących

1 W pewnych przypadkach istotne bywają również inne cechy prozodyczne, a mianowicie intonacja i akcent zdaniowy uwydatniający wybrany komponent tekstu (Sierosławska 2008; Danielewiczowa 2015), a także cechy głosek (drżące, syczące, szumiące, zwarte), o czym za chwilę.

2 Na ten aspekt ukształtowania rytmicznego zwracała uwagę Maria Renata Mayenowa, która pisała: „Formy metryczne niejako alienują się, stają się wartościami same dla siebie lub przynajmniej sygnałami tych wartości. Jeśli trochej w polskiej kulturze występuje często w funkcji wiersza utworów dla dzieci, można użyć tej formy we wstrząsającym okupacyjnym wierszu o dzieciach, skierowanym tylko pozornie do nich: »Ucz się, dziecko, polskiej mowy«, wygrywając tę jego wartość jako mechanizm, który przedstawia semantykę całego tekstu: nadaje mu charakter groteski, ponurej niespójności" (Mayenowa 1979: 423).

3 Dostępne pod linkiem: https://www.youtube.com/watch?v=CofN4q_qvoo. 
w większości przypadków na co drugiej sylabie, a ponadto oddzielaniem kolejnych zgłosek mikropauzami (staccato). Za sprawą prostego, miarowego układu akcentowego, urywanego toku artykulacyjnego oraz specyficznego, niemelodyjnego tonu głosu odnosimy pożądane przez twórcę wrażenie, jakby bohaterowie nie byli żywi, lecz mechaniczni, co daje efekt komizmu ${ }^{4}$ i groteski.

Niektóre jakości dźwiękowe „zadane” tłumaczowi przez autora pierwotnego tekstu oraz kompozytora melodii można było w polskiej translacji oddać stosunkowo łatwo, na przykład rytm trocheiczny, gdyż paroksytoneza jest w polszczyźnie naturalna i powszechna ${ }^{5}$. Wyzwanie stanowiły natomiast jamby $i$ anapesty $z$ akcentem na ostatniej sylabie i z tego zapewne względu w polskich wersjach piosenki obserwujemy przesunięcia akcentuacyjne wobec pierwowzoru:

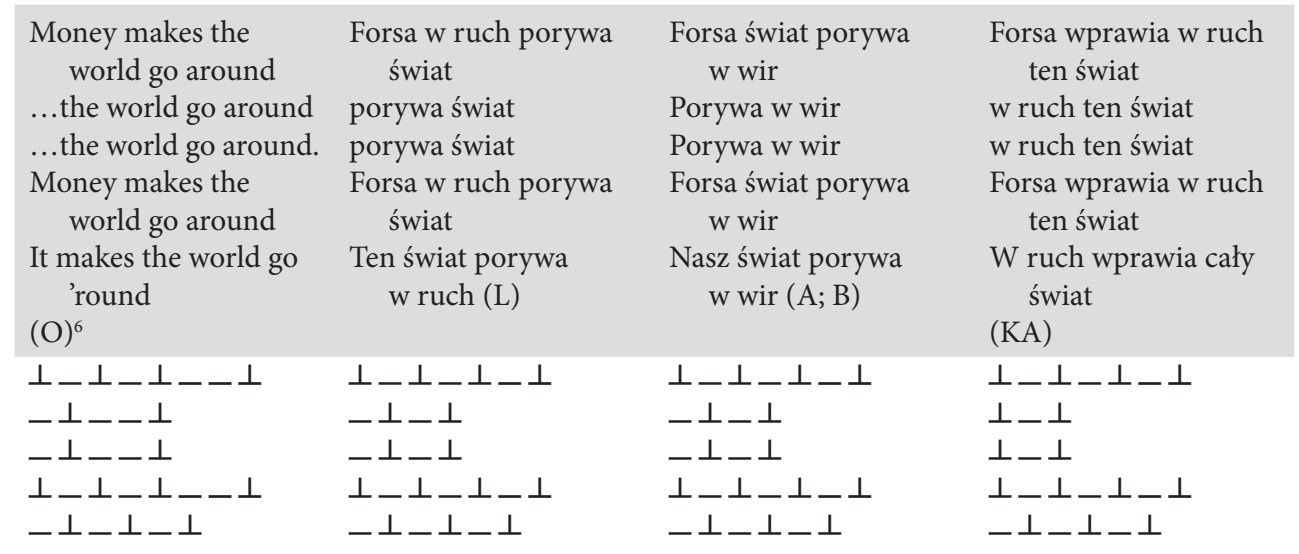

4 Zgodnie z teorią automatyzmu Henriego Bergsona, którego zdaniem „komicznem będzie takie ugrupowanie czynów i zdarzeń, które da nam złudzenie życia, a równocześnie sprawi wrażenie w ruch wprawionego mechanizmu” (Bergson 1902: 59; por. Buttler 1968/2001: 19-20).

5 Warto przy tym dodać za M.R. Mayenową, że „Mimo iż dwusylabowe wyrazy stanowią najliczniejszą klasę w słowniku polskim, wydaje się, iż trochej utrzymuje się trudniej niż amfibrach, który wykorzystuje z łatwością trzy najliczniejsze klasy słownika: jedno-, dwu- i trzysylabowe wyrazy" (Mayenowa 1979: 406).

6 Źródła oznaczyłam symbolami literowymi: 1) O - oryginał angielski (Masteroff, Ebb 1998); 2) A odnaleziony w archiwum maszynopis z odręcznymi poprawkami Młynarskiego (Money); 3) L libretto otrzymane od reżyserki (Eweliny Pietrowiak), sygnowane nazwiskiem Młynarskiego (Masteroff, Ebb 2010); 4) B - zapis własny na podstawie wykonania Michała Bajora; 5) KA - zapis własny na podstawie wykonania Joanny Kołaczkowskiej i Damiana Aleksandra. 


\begin{tabular}{|c|c|c|c|}
\hline $\begin{array}{l}\text { A mark, a yen, a buck } \\
\text { or a pound } \\
\text {... a buck or a pound } \\
\text {... a buck or a pound. } \\
\text { Is all that makes the } \\
\text { world go around } \\
\text { That clinking, clanking } \\
\text { sound } \\
\text { Can make the world } \\
\text { go 'round }(\mathrm{O})\end{array}$ & $\begin{array}{l}\text { Marka, dolar, yen i lir } \\
\text { yen i lir } \\
\text { yen i lir } \\
\text { cały świat porywa } \\
\text { w wir } \\
\text { ich wdzięczny, } \\
\text { dźwięczny tryl } \\
\text { ten świat porywa w wir } \\
\text { (L) }\end{array}$ & $\begin{array}{l}\text { Bo marka, dolar, jen } \\
\text { czy lir } \\
\text { Czy jen (yen) czy lir... } \\
\text { Czy jen (yen) czy lir... } \\
\text { Nasz stary świat pory- } \\
\text { wa w wir } \\
\text { Nasz świat porywa } \\
\text { w wir } \\
\text { Ich wdzięczny, } \\
\text { dźwięczny tryl } \\
\text { (A; B) }\end{array}$ & $\begin{array}{l}\text { Marka, dolar jen lub } \\
\text { funt } \\
\text { jen lub funt } \\
\text { jen lub funt } \\
\text { Wprawiają w ruch ten } \\
\text { cały świat } \\
\text { Ten dźwięk, ten brzęk, } \\
\text { ten blask } \\
\text { W ruch wprawia cały } \\
\text { świat (KA) }\end{array}$ \\
\hline $\begin{array}{l}-\perp-\perp-\perp--\perp \\
-\perp--\perp \\
-\perp-\perp \perp \\
-\perp-\perp-\perp--\perp \\
-\perp-\perp-\perp \\
-\perp-\perp-\perp\end{array}$ & $\begin{array}{l}\perp-\perp-\perp-\perp \\
\perp-\perp \\
\perp-\perp \\
\perp-\perp-\perp-\perp \\
-\perp-\perp-\perp \\
-\perp-\perp-\perp\end{array}$ & $\begin{array}{l}-\perp-\perp-\perp-\perp \\
-\perp-\perp \\
-\perp-\perp \\
-\perp-\perp-\perp-\perp \\
-\perp-\perp-\perp \\
-\perp-\perp-\perp\end{array}$ & $\begin{array}{l}\perp-\perp-\perp-\perp \\
\perp-\perp \\
\perp-\perp \\
-\perp-\perp-\perp-\perp \\
-\perp-\perp-\perp \\
-\perp-\perp-\perp\end{array}$ \\
\hline
\end{tabular}

Kiedy porównamy schematy akcentowania zastosowane we wszystkich wariantach przekładu z pierwotnym modelem, zauważymy, że w polskich odmiankach zrezygnowano z rytmu anapestycznego, upraszczając tym samym kształt prozodyczny. Realizacje sceniczne dowodzą jednak, że taka modyfikacja nie skutkuje brakiem korelacji frazy tekstowej z frazą muzyczną ani też nie wpływa na możliwość pełnienia przez rytm funkcji reprezentatywnej: bardzo prosty, naprzemienny układ sylab akcentowanych i nieakcentowanych w polskich wersjach językowych pozwolił na zachowanie satyryczno-groteskowego rysunku postaci, co dobrze widać w wykonaniu Michała Bajora?.

W tłumaczeniu obserwujemy także dążność do uzyskania zgodnego z oryginałem układu rymów. Konsekwentnie zastosowano regularne rymy męskie, na ogół dokładne ${ }^{8}$, co w polszczyźnie nie było łatwe, gdyż nasz zasób pełnoznacznych słów jednowyrazowych jest bardzo ograniczony (Barańczak 1983: 75-76) ${ }^{9}$. Pozycja rymowa jest istotna ze względów stylistycznych i semantycznych, gdyż przykuwa uwagę słuchaczy. Wskazane jest zatem, aby wyraz, który się w niej znajduje, nie raził niewłaściwym nacechowaniem i żeby jego znaczenie było w jakiejś mierze ważne dla całości (ibid.: 8o). Jeżeli uwzględni się wszystkie te uwarunkowania, nietrudno zro-

7 Dostępne pod linkiem: https://www.youtube.com/watch?v=UfnpSF_KApI.

8 Tylko w jednej odmiance użyty został asonans: blask - świat. Zauważmy ponadto, że udało się uniknąć transakcentacji, którą Młynarski uważał za „nieznośną” (Młynarski 1983: 42; podobnie Pisarkowa 1998: 105).

9 O tej sprawie pisała Magdalena Barczewska-Skarboń w kontekście przekładu musicalu Cats: „Język polski posiada mniejszą niż język angielski liczbę wyrazów jednosylabowych nacechowanych semantycznie, co bardzo ograniczyło tłumacza libretta i spowodowało, że pełne treści wiersze w przekładzie zostały ogołocone z poetyckich drobiazgów składających się na wartość artystyczną dzieła" (Barczewska-Skarboń 2005: 178). 
zumieć, dlaczego warianty przekładowe refrenu Money... różnią się właśnie w klauzulach. Tłumacz brał tu pod uwagę dwa rzeczowniki jednosylabowe, a mianowicie wir i świat. Polszczyzna dawała mu znaczną swobodę syntaktyczną, w związku z czym mógł rozmaicie kształtować szyk wypowiedzenia w celu uzyskania takiej czy innej postaci dźwiękowej.

W rezultacie powstały wariantywne, bliskoznaczne frazy: „forsa wprawia w ruch ten świat”, „forsa w ruch porywa świat” oraz „forsa świat porywa w wir”. Świat, jak stwierdziła Anna Barańczak, jest wyrazem o najwyższej frekwencji w pozycji rymu męskiego w polskiej piosence XX w., podczas gdy wir nie znalazł się w stworzonym przez badaczkę wykazie często rymujących się słów (ibid.). Użycie tego ostatniego rzeczownika jest zatem niebanalne i intrygujące ${ }^{10}$. Nietrudno wskazać inne jeszcze zalety jego obecności w refrenie, taką na przykład, że zawiera $r$, dzięki czemu służy instrumentacji głoskowej. Zastosowana w oryginale gra fonetyczna world go around przybrała w polskiej wersji językowej inną postać niż w angielskiej ze względu na fundamentalne różnice artykulacyjne i akustyczne między sonorantami (EJO) zapisywanymi w obu kodach tą samą literą ${ }^{11}$. Charakterystyczny, powtarzalny efekt dźwiękowy pierwowzoru - world go around - wykazujący pewne analogie do rozziewu (hiatus), został zastąpiony nagromadzeniem głoski drżącej: $r$ pojawia się aż trzykrotnie w krótkich, trzy- lub pięciowyrazowych frazach: „forsa ${ }^{12}$ wprawia w ruch [...]”, „forsa [...] porywa w wir" ${ }^{13}$. Widać więc, że Młynarskiemu zależało na tym, by ocalić w tłumaczeniu ciekawą grę fonetyczną ${ }^{14}$. Wydaje się jednak, że artysta, który niewątpliwie zdawał sobie sprawę z walorów fonetycznych słowa wir, nie był pewien, czy jest to najwłaściwszy wybór leksykalny: w maszynopisie (A) wir pojawia się w obu częściach refrenu, natomiast w drukowanej wersji libretta (L) pada już tylko w części drugiej, zaś jedna z odmianek wykonywanych dziś na estradzie (KA) nie zawiera go wcale, tak jakby ktoś doszedł do wniosku, że wyraz ów jest z jakichś

$10 \mathrm{O}$ problemach natury estetycznej związanych z powtarzalnością rozwiązań stosowanych przez tłumaczy Jerzy Zagórski pisał: „Muzyka wyolbrzymia podłożone pod nią słowa. [...] W prozie ani zauważysz, że użyłeś słowa los na jednej stronie, a cios na innej [...]. Ale gdy pójdziesz na kilka oper i w każdej posłyszysz te same los i cios, i to po kilka razy w akcie, zamrze ci głos i stanie włos na głowie" (Zagórski 1975: 361).

11 W wykonaniu Lizy Minnelli dodatkowym walorem jest imitowanie niemieckiego sposobu wymawiania głoski $r$.

12 Najważniejszy wybór leksykalny, czyli oddanie tytułowego, neutralnego stylistycznie money nacechowaną kolokwialnie forsą (wybraną z licznego zbioru synonimów), przypuszczalnie był także motywowany fonetycznie.

13 Wir motywuje też użycie nazwy waluty nieobecnej w pierwowzorze: lir, która daje rym dokładny i służy instrumentacji głoskowej.

14 Nie udało się to w przypadku onomatopeicznego efektu przesypujących się monet (clinking, clanking sound). W jednym $\mathrm{z}$ wariantów tłumaczenia pojawia się wprawdzie tryl, może on jednak ewokować brzęk metalu jedynie za sprawą kontekstowych „sygnałów wywoławczych” (Pszczołowska 1977: 44; podobnie Bańko 20o8: 17-18), co jest tu dosyć problematyczne. 
względów nieodpowiedni. Wydaje się, że problem dotyczy tu innej płaszczyzny organizacji wypowiedzi, a mianowicie obrazowania.

\section{Ekwiwalencja semantyczna: wybór leksyki a obrazowanie}

W kognitywnym nurcie teorii translacji przyjmuje się, że zasadniczą ,jednostkę tekstu” stanowi właśnie „obraz” („scena”) (Tabakowska 2001: 99), a „stwierdzenie ekwiwalencji dwóch tekstów - oryginału i przekładu - jest [...] stwierdzeniem ekwiwalencji dwóch konceptualizacji" (ibid.: 161-162; podobnie Hejwowski 2004: 133 i 156). Ważnym założeniem semantyki kognitywnej jest to, że wyrazy i inne struktury mowy użyte w wypowiedziach znaczą w taki sposób, iż poprzez sygnały leksykalne i gramatyczne dają dostęp do utrwalonych w umysłach użytkowników języka intersubiektywnych wyobrażeń o rzeczywistości: „obrazów”, „scen”, „skryptów" (Mandler 2004: 99-136). W refrenie Money... taką sceną są obroty naszej planety. Przekład musiał zatem dostarczyć „sygnałów tekstowych” (Hejwowski 2004: 69), czyli takich słów i wyrażeń, które tę „rzeczywistość mentalną” (ibid.) będą niezawodnie ewokować. Można mieć wątpliwości, czy rzeczownik wir spełnia ten warunek, gdyż silnie kojarzy się on z ruchem nie ciał kosmicznych, lecz wody, co może w sposób niezamierzony przez nadawcę wpływać na wyobrażenia powstające $\mathrm{w}$ trakcie słuchania piosenki.

Zwróćmy ponadto uwagę, że oryginalna fraza money makes the world go around nie przynosi negatywnej charakterystyki aksjologicznej, przeciwnie, można się w niej dopatrywać wartościowania pozytywnego (ujętego w ironiczny nawias): wszak obroty Ziemi są naturalne i pożądane. Tymczasem wir - z wyjątkiem kontekstu wirowania $w$ tańcu - ma zwykle ujemne konotacje: wiry wciągają pływaków, a także łodzie i statki, bywają zatem niebezpieczne. Są one także, niezależnie od skali, w jakiej występują, zjawiskami o dużej dynamice, niepoddającymi się kontroli człowieka, co również stanowi źródło ujemnego wartościowania, widocznego w takich zleksykalizowanych metaforach i metonimiach, jak: wir 'coś kłębiącego się w bezładnym ruchu, kłębowisko' (SJPD), wir spraw, wir wydarzeń 'zdarzenia następujące szybko po sobie i przebiegające w sposób niekontrolowany' (ISJP), zawirowania 'nieoczekiwane komplikacje w przebiegu jakichś spraw' (ibid.), myśli a. obrazy wiruja nam $w$ głowie 'mamy zawroty głowy z powodu choroby lub silnych emocji; jesteśmy oszołomieni' (ibid.). W procesie odbioru polskich wersji piosenki prawdopodobna jest aktualizacja tych skojarzeń, będących przecież częścią wiedzy potocznej, należy zatem stwierdzić, że użycie rzeczownika wir zmniejsza ekwiwalencję semantyczną przekładu. Nie jest jednak tak, że innowacja Młynarskiego się nie broni. Jeśli spojrzymy na nią z perspektywy pragmatycznej i uwzględnimy satyryczno-ironiczny charakter refrenu, możemy dojść do wniosku, że polski tłumacz wyraził to, co w oryginale zostało tylko zasugerowane, czyli myśl o negatywnym wpływie postaw 
materialistycznych na życie społeczne, które wymyka się spod kontroli i dąży do destrukcji.

\section{Różnice i analogie stylistyczne}

Wysiłki tłumacza zmierzające do jak najpełniejszej ekwiwalencji obserwujemy także na płaszczyźnie stylistycznej, co dobrze widać w pierwszej strofie piosenki:

\begin{tabular}{|c|c|c|c|c|}
\hline $\begin{array}{l}\text { If you happen to } \\
\text { be rich } \\
\text { And you find you } \\
\text { are left } \\
\text { by your lover, } \\
\text { And you moan } \\
\text { and you groan } \\
\text { quite a lot. }(\mathrm{O})\end{array}$ & $\begin{array}{l}\text { Gdy masz szmal, } \\
\text { to chociaż się } \\
\text { zdarzy, że } \\
\text { zdradzi cię } \\
\text { Twój kochanek } \\
\text { lub kochanka } \\
\text { ucieknie hen } \\
\text { w świat. (B) }\end{array}$ & $\begin{array}{l}\text { Gdyś bogata }^{15} \text {, } \\
\text { może się } \\
\text { zdarzyć, że } \\
\text { rzuci cię } \\
\text { Ten najdroższy, } \\
\text { a ty w płacz, } \\
\text { cała w łzach. } \\
\text { (KA) }\end{array}$ & $\begin{array}{l}\text { Gdy masz szmal, } \\
\text { to chociaż się } \\
\text { zdarzy, że } \\
\text { zdradzi cię } \\
\text { twój kochanek } \\
\quad \text { lub kochanka } \\
\text { ucieknie hen } \\
\text { w świat. (L) }\end{array}$ & $\begin{array}{l}\text { Gdy masz fart }{ }^{16} \text {, } \\
\text { to chociaż się } \\
\text { zdarzy, że } \\
\text { zdradzi cię } \\
\text { twój kochanek } \\
\quad \text { lub kochanka } \\
\text { ucieknie hen } \\
\text { w świat. (A) }\end{array}$ \\
\hline $\begin{array}{l}\text { You can take it on } \\
\text { the chin, } \\
\text { Call a cab and } \\
\text { begin } \\
\text { to recover } \\
\text { On your 14-ka- } \\
\text { rat yacht! } \\
\text { WHAT!? (O) }\end{array}$ & $\begin{array}{l}\text { Inny by wylewał } \\
\text { łzy, } \\
\text { lecz nie ty, } \\
\text { zwłaszcza gdy } \\
\text { masz na stanie } \\
\text { pełnomorski, } \\
\text { piękny jacht. (B) }\end{array}$ & $\begin{array}{l}\text { Nie załamuj wte- } \\
\quad \text { dy rąk, } \\
\text { spróbuj znów } \\
\text { znaleźć go, } \\
\text { a odnajdziesz } \\
\text { swój szczero- } \\
\text { złoty jacht. } \\
\text { Jacht?! (KA) }\end{array}$ & $\begin{array}{l}\text { Inny by wylewał } \\
\quad \text { łzy, } \\
\text { lecz nie ty, } \\
\text { zwłaszcza gdy } \\
\text { masz na stanie } \\
\text { pełnomorski, } \\
\text { piękny jacht... } \\
\text { Ach? (L) }\end{array}$ & $\begin{array}{l}\text { Inny by wylewał } \\
\text { łzy } \\
\text { lecz nie ty, } \\
\text { zwłaszcza gdy } \\
\text { masz na stanie... } \\
\text { pełnomorski, } \\
\text { piękny yacht. } \\
\text { (A) }\end{array}$ \\
\hline
\end{tabular}

Bohater oryginału opuszczony przez ukochanego/ukochaną (lover) jęczy i stę$k a$ (moan and groan). Bogactwo pomaga mu jednak uporać się z przeciwnościami losu: take it on the chin. Ów frazeologizm bazuje przypuszczalnie na scenariuszu walki na pięści (LID), podczas której zawodnik otrzymuje cios w szczękę, zawiera więc element brutalności i reprezentuje styl niski („an informal expression”, CCED, podobnie moan 'complaint'). Tymczasem Młynarski, używając form trybu przypuszczającego, stworzył alternatywny obraz postaci, która na utratę obiektu miłości reaguje w sposób sentymentalno-romantyczny: wylewa łzy. Obserwujemy tu zatem wyraźną różnicę w wymiarze obrazowania, lecz także tylu: zwroty wylewać łzy czy cała $w$ łzach mają charakter nie kolokwialny, a wręcz przeciwnie - książkowy.

Intrygujące, że w innym fragmencie tłumacz podjął decyzję o ukształtowaniu swojego tekstu w stylu niższym niż w oryginale:

15 Forma żeńska wynika $\mathrm{z}$ tego, że fragment ów śpiewa mężczyzna, który zwraca się do kobiety.

16 W maszynopisie szmal przekreślony odręcznie i w to miejsce wpisany fart. 


\begin{tabular}{|c|c|c|c|c|}
\hline $\begin{array}{l}\text { Money makes } \\
\text { the world go } \\
\text { around }\end{array}$ & $\begin{array}{l}\text { Forsa świat pory- } \\
\text { wa } \mathrm{w} \text { wir } \\
{[\ldots]}\end{array}$ & $\begin{array}{l}\text { orsa wprawia } \\
\text { w ruch ten } \\
\text { świat }\end{array}$ & $\begin{array}{l}\text { Forsa } w \text { ruch } \\
\text { porywa świat } \\
{[\ldots]}\end{array}$ & $\begin{array}{l}\text { Forsa świat pory- } \\
\text { wa w wir } \\
{[\ldots]}\end{array}$ \\
\hline $\begin{array}{l}\text { Of that we both } \\
\text { are sure... } \\
\text { on being poor! } \\
\text { (O) }\end{array}$ & $\begin{array}{l}\text { Ten, co ma gołą } \\
\text { „de”, } \\
\text { najlepiej wie (B) }\end{array}$ & $\begin{array}{l}{[\ldots]} \\
\text { A my, co tu kryć, } \\
\text { nie mamy nic } \\
\quad(\mathrm{KA})\end{array}$ & $\begin{array}{l}\text { My dwoje co tu } \\
\text { kryć } \\
\text { nie mamy nic (L) }\end{array}$ & $\begin{array}{l}\text { Ten, co ma gołe } \\
\text { „d...” } \\
\text { Najlepiej wie (A) }\end{array}$ \\
\hline
\end{tabular}

W pierwowzorze sytuacja osób biednych została nazwana wprost, w sposób nienacechowany: being poor. $\mathrm{W}$ dwu wariantach tłumaczenia również zastosowano frazę neutralną stylistycznie: nie mamy nic, w dwu zaś innych użyto potocznego, rubasznego zwrotu: mieć goła „de”; mieć gołe $d$... Zarówno w oryginale, jak i w przekładzie została więc zastosowana gra polegająca na zderzaniu ze sobą różnych stylów, obserwujemy ją jednak w innych fragmentach tekstu.

Pierwsza strofa wprowadza też pierwiastek absurdalnego humoru: jacht, na którym bogacz ma dojść do siebie (recover) po utraconej miłości, jest w oryginale 14-karatowy, karat zaś to 'jednostka masy stosowana w obrocie kamieniami szlachetnymi i perłami' (SJP PWN). Na poziomie znaczenia leksykalnego wyrażenie 14-karat yacht! jest zatem nonsensowne i dlatego następuje po nim, w pozycji rymowej, zapisany wersalikami zaimek WHAT!?. Surrealistyczny charakter 14-karatowego jachtu został oddany w jednym tylko wariancie przekładu, w wyrażeniu szczerozłoty jacht: zawiera ono wprawdzie aluzję nie do kamieni szlachetnych, lecz do kruszcu, ale wykorzystuje analogiczny mechanizm metonimii. W pozostałych odmiankach zrezygnowano $\mathrm{z}$ tego dowcipu: jacht (yacht) został w nich określony przydawkami pełnomorski i piękny.

Element absurdu pojawił się natomiast w przekładzie kolejnej strofy, tym razem portretującej biedaka. Zgodnie z konwencją językowo-kulturową zarówno angielszczyzny, jak i polszczyzny można go rozpoznać po ubraniu niezapewniającym ciepła oraz po braku (odpowiednich) butów (oryg.: you haven't any shoes on your feet, przekł.: „bose nogi masz”, „buty krzyczą jeść”, por. NKPP buty pić prosza). Ubogi bohater szuka pocieszenia u księdza sportretowanego w stereotypowy, karykaturalny sposób (fat little pastor; „tłusty klecha”; „klecha, co z ambony grzmi”). Pojawia się również trzecia postać: upersonifikowany głód. Scena $\mathrm{z}$ jego udziałem nawiązuje $\mathrm{w}$ oryginale do skryptu utrwalonego $\mathrm{w}$ przysłowiu: When poverty comes in at the door, love flies out of the window (ODP), przy czym Ebb wprowadził tu niewielka modyfikację: gdy głód puka do okna, miłość wyfruwa drzwiami: But when hunger comes [...] See how love flies out the door.... Angielskie przysłowie ma swój pierwowzór łaciński, który przeniknął także do polszczyzny, gdzie przyjął postać frazy: „Gdy bieda wchodzi drzwiami, miłość oknem wylatuje” (NKPP). Tymczasem Młynarski, jak się wydaje, albo nie wziął pod uwagę tej frazy, albo uznał, że jej wykorzystanie w przekładzie nie jest możliwe. W dwóch wariantach odnajdujemy wprawdzie scenę ucieczki przed głodem, niemniej jednak pominięto w niej 
postać miłości: „gdy zapuka w okno głód / [...] Razem z klechą Bóg / Przez komin zmyka precz!" (B, podobnie A). W konsekwencji strofa nabrała charakteru groteskowo-nonsensownego, co jest w stosunku do oryginału istotną zmianą stylistyczną, a zwłaszcza semantyczną.

\section{Podsumowanie}

Z zestawienia wariantów przekładu Money... wyłania się pewna hierarchia poziomów ekwiwalencji przyjęta w tłumaczeniu utworu słowno-muzycznego. Hierarchia ta, w pewnej mierze uwarunkowana specyfiką gatunku, nosi również znamiona subiektywizacji i okazuje się nieostateczna, zmienna w czasie: stąd przypuszczalnie wzięły się kolejne odmianki. Analizy skłaniają do wniosku, że sprawami priorytetowymi były dla Młynarskiego znaczenie intencjonalne (rozumiane globalnie, jako ogólna wymowa tekstu), a także - wbrew postulatom zawartym w niektórych pracach teoretycznoprzekładowych (Bryll 2005: 160; por. także Maliszewski 2005: 142-143) - brzmienie: rytm i rym. Tłumacz-artysta patrzył na adaptowany przez siebie obcojęzyczny utwór nie tylko linearnie, lecz także całościowo. Starał się zachować jak najwięcej walorów oryginału w zakresie semantyki i obrazowania, a także stylu. Jeśli z pewnych względów nie udało mu się oddać danej jakości estetycznej (na przykład kontrastu, groteski, absurdu) w pierwotnym fragmencie tekstu, starał się w miarę możliwości zrekompensować to polskim odbiorcom w innej jego partii. Zdawał sobie przy tym sprawę, że stworzenie w polszczyźnie wartościowej reprezentacji dzieła słowno-muzycznego wymaga wejścia w rolę współtwórcy i czuł się w tej roli całkiem swobodnie, co nie dziwi, gdyż jego główną domeną było pisanie piosenek, nie zaś ich tłumaczenie. Korzystając z artystycznej autonomii, co uważał za nieuchronne i nieodzowne (Młynarski 1983: 41-42), skupiał się nie tyle na wierności pierwotnemu tekstowi, ile na tym, by zapewnić widowni takie przeżycie estetyczne, jakiego sam doświadczał, obcując z oryginałem.

\section{Źródła}

Masteroff J., Евв F., 1998, Cabaret, [on-line:] http://www.floridarep.org/wp-content/up loads/2017/08/o8-Cabaret-Script.pdf.

Masteroff J., Евв F., 2010, Cabaret, przeł. K. Piotrowski (libretto), W. Młynarski (piosenki), komputeropis, archiwum prywatne E. Pietrowiak.

Money: W. Młynarski, Money, Money, maszynopis tłumaczenia, archiwum Wojciecha Młynarskiego, Muzeum Literatury w Warszawie. 


\section{Literatura}

Bańko M., 2008, Współczesny polski onomatopeikon. Ikoniczność w języku, Warszawa.

BARAŃCZAK A., 1983, Słowo w piosence. Poetyka współczesnej piosenki estradowej, „Rozprawy Literackie", t. 41, Wrocław.

BarczewsKa-Skarboń M., 2005, Koty Eliota śpiewane po polsku, [w:] P. Fast (red.), Kultura popularna a przekład, „Studia o Przekładzie”, nr 18, Katowice, s. 175-185.

BERGSON H., 1902, Śmiech. Studyum o komizmie, Lwów, [on-line:] https://upload.wikimedia. org/wikipedia/commons/9/96/Smiech-studyum_o_komizmie.pdf.

Bryll A., 2005, Cohen mówiony i śpiewany, czyli o przekładzie poetyckim i melicznym tekstów piosenek, [w:] P. Fast (red.), Kultura popularna a przekład, „Studia o Przekładzie”, nr 18, Katowice, s. 159-173.

Buttler D., 1968/2001, Polski dowcip językowy, wyd. 3 z uzup., „Klasyka Językoznawstwa Polskiego", Warszawa.

CCED: J. Sinclair (red.), Collins COBUILD English Dictionary, London 1995.

Danielewiczowa M., 2015, Wstęp, [w:] M. Danielewiczowa i in. (red.), Sens i brzmienie, „Prace Językoznawcze Instytutu Filologii Polskiej UKSW”, t. 7, Warszawa, s. 7-12.

EJO: K. Polański (red.), Encyklopedia językoznawstwa ogólnego, wyd. 2 popr. i uzup., Wrocław - Warszawa - Kraków 1999.

Hejwowski K., 2004, Kognitywno-komunikacyjna teoria przekładu, „Przekład, Mity i Rzeczywistość", Warszawa.

ISJP: M. Bańko (red.), Inny słownik języka polskiego PWN, t. I-II, Warszawa 2000.

LEWICKI R., 2017, Zagadnienia lingwistyki przekładu, Lublin.

LID: The Idioms. Largest Idioms Dictionary, [on-line:] https://www.theidioms.com/ take-it-on-the-chin/.

MaliszewsKi J., 2005, "Nic dwa razy się nie zdarza” - strategia poetyckiego i melicznego przekładu wiersza Wisławy Szymborskiej na język angielski i niemiecki, [w:] P. Fast (red.), Kultura popularna a przekład, „Studia o Przekładzie”, nr 18, Katowice, s. 141-157.

Mandler J.M., 2004, Opowiadania, skrypty i sceny. Aspekty teorii schematów, „Pragmatyka i Semantyka Mowy", t. 1, Kraków.

Mayenowa M.R., 1979, Poetyka teoretyczna. Zagadnienia języka, wyd. 2 uzup. i popr., „Vademecum Polonisty”, Wrocław.

MŁynARski W., 1983, ${ }^{* * *}$ (List do red. Bogusława Wróblewskiego), „Akcent” 14, nr 4, s. 39-43.

NKPP: J. Krzyżanowski (red.), Nowa księga przysłów i wyrażeń przysłowiowych polskich, t. 1-4, Warszawa 1969-1978.

ODP: J. Simpson, J. Speake (red.), The Oxford Dictionary of Proverbs, [on-line:] https://www. oxfordreference.com/view/10.1093/acref/9780199539536.001.00o1/acref-9780199539536.

Pisarkowa K., 1998, Pragmatyka przekładu. Przypadki poetyckie, „Prace Instytutu Języka Polskiego", nr 106, Kraków.

PszczoŁowska L., 1977, Wiersz: podstawowe kategorie opisu, cz. 2: Eufonia, z. 2: Instrumentacja dźwiękowa, „Poetyka: Zarys Encyklopedyczny”, dział 3: „Wersyfikacja”, t. 2, Wrocław.

SierosŁawsKa E., 2008, Fraza muzyczna a fraza tekstowa. Prozodia w przekładzie arii operowych, „Prace Monograficzne - Akademia Pedagogiczna im. Komisji Edukacji Narodowej w Krakowie", nr 486, Kraków.

SJPD: W. Doroszewski (red.), Słownik języka polskiego, t. I-XI, Warszawa 1958-1969. 
SJP PWN: Słownik języka polskiego PWN, [on-line:] sjp.pwn.pl.

ТАвакошsкA E., 2001, Językoznawstwo kognitywne a poetyka przekładu, „Językoznawstwo Kognitywne", nr 4, Kraków.

ZAGórski J., 1975, Tłumaczenie tekstów do muzyki, [w:] S. Pollak (red.), Przekład artystyczny. O sztuce tłumaczenia, księga druga. Praca zbiorowa, Wrocław, s. 353-366.

\section{Prosody, Semantics and Style. On the Hierarchy of Levels of Equivalence in the Translation of Cabaret Songs (Case Study: Polish Versions of Fred Ebb's Money....) Abstract}

The article is a case study and contains a comparative analysis of four variants of the Polish translation of Fred Ebb and John Kander's song Money... from the musical "Cabaret". The author of the translation is Wojciech Młynarski, one of the most respected Polish songwriters of the second half of the twentieth century. In the study, an assumption is made that Młynarski, who repeatedly changed versions of his translation, sought to create the most faithful rendition of the songs from the musical for the needs of the Polish stage. His efforts can be observed at four levels of text organization. The translator aimed mainly for sound equivalence, i.e. conformity with the original song in terms of rhythm (word stress), rhyme (consonance) and voice instrumentation and, to a lesser extent, sound imitation. He also cared about pragmatic equivalence by rendering into Polish the original intentions, with particular emphasis on the modes of indirect communication, such as irony and satire. However, other aspects of equivalence remained in the background. Not everywhere the translator managed to keep the cognitive equivalence, i.e. convergence of imagery, by translating scenes and scenarios that were part of cultural knowledge into parallel ones and, more broadly, by trying to evoke similar images in the mind of the reader and listener. His efforts to achieve the effect of broadly understood stylistic equivalence were also noteworthy; only to a small extent they consisted in giving the right stylistic coloring to the individual lexical items which had their English equivalents, and they mainly boiled down to translating stylistic games that did not necessarily cover the same fragments of the song, though were usually based on the same mechanism (a clash between low and high style, absurdity). The analysis shows that the translator adopted tabular rather than linear approach to the original. 